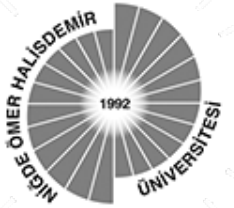

Araştırma Makalesi

Research Article
Ömer Halisdemir Üniversitesi İktisadi ve İdari Bilimler Fakültesi Dergisi Yll: 2019 Cilt-Sayl: 12(4) ss: $454-465$

Academic Review of Economics and Administrative Sciences Year: 2019 Vol-Issue: 12(4) pp: 454-465

http://dergipark.gov.tr/ohuiibf/

ISSN: 2564-6931

DOI: 10.25287/ohuiibf.507759

Geliş Tarihi / Received: 03.01.2019

Kabul Tarihi / Accepted: 27.09.2019

\title{
EXPORT-LED GROWTH HYPOTHESIS IN DEVELOPING COUNTRIES: ECONOMETRIC EVIDENCE FROM BANGLADESH
}

\author{
Harun BAL $L^{1}$ \\ Abdulla Hil MAMUN ${ }^{2}$ \\ Shahanara BASHER ${ }^{3}$ \\ Mohammad Rahim UDDIN ${ }^{4}$ \\ Masrurul MOWLA
}

\begin{abstract}
The meticulous growth of both export and output of Bangladesh following the inception of trade liberalization and export promotion in the late 1970s through 2010s gravely underscore the export-led growth (ELG) hypothesis for the economy. The present study examines both the short-run causality and long-run dynamics between export and economic growth in order to confirm whether the ELG hypothesis works for Bangladesh drawing data for the period from 1974 to 2015. The long-run dynamics between export and output growth based on ARDL Bounds testing approach suggests that ELG is evident for Bangladesh. In order to examine the short-run causality, the study performs Toda-Yamamoto causality test along with the conventional Granger causality test. While the Granger causality analysis identifies a bidirectional causal relationship between exports and output growth, the Toda-Yamamoto approach confirms a unidirectional causality that runs from exports to output growth. A unidirectional causal relationship from export to output growth is necessary for the validity of the ELG hypothesis. However, bidirectional causality between export and output implies that growth in exports reinvigorates output growth which, in turn, reinforces export expansion and thereby further underlines the validity of the ELG hypothesis.
\end{abstract}

Keywords

: Export-led Growth, Bounds Test, Granger Causality, Toda-Yamamoto, Bangladesh.

Jel Classification

:F14, F43.

\footnotetext{
${ }^{1}$ Prof., Dr., Cukurova University, Faculty of Economics and Administrative Sciences, Department of Economics, harunbal@cu.edu.tr, ORCID: 0000-0003-0878-8253

${ }^{2}$ Assoc. Prof. Dr., International Islamic University Chittagong (Bangladesh), The Scientific and Tecnological Research Council of Turkey (TUBITAK), ahm.economics@gmail.com, ORCID: 0000-0001-6997-4434

${ }^{3}$ Phd Fellow, Cukurova University, Department of Economics, sb.ripon@gamail.com, ORCID: 0000-0001-5816-9050

${ }^{4}$ Asst.Prof. Dr., International Islamic University Chittagong (Bangladesh), mructg@gmail.com, ORCID: 0000-0001-51127253

${ }^{5}$ Assoc. Prof. Dr., International Islamic University Chittagong (Bangladesh), mmmiiuc@gmail.com, ORCID: 0000-00028326-8066
} 


\section{INTRODUCTION}

The export-led growth (ELG) strategy is being followed by many developing countries of the world with an aim to accelerate the industrialization process of the states and thereby speed up their economic growth (Krugman, 2008). It enables countries to enjoy comparative advantage for their exporting goods (Heckscher \& Ohlin, 1991; Dornbusch et al, 1980) exploit economies of scale (Helpman and Krugman, 1985), achieve efficiency in production through increased competition (Balassa, 1978) and promote diffusion of technological knowledge due to foreign market competition (Awokuse, 2003) that is vital for economic development and growth in the long-run. Most of the developing economies followed closed macroeconomic policies. Until the late 1960s, import substitution industrialization policies were widely applied. East Asian countries had changed their strategy during the 1970s- they replaced their import substitution policies by export promotion (Chandra \& Sahoo, 2007). All the high-performance Asian economies (HPAEs) with outstanding economic growth took various policies and strategies to support export growth and consequently the export performance of these economies was revealed in their export performances. In 1965, World exports by the HPAEs as a group was 7.9 percent, which augmented remarkably in 1980 (13.1 percent) and at the end of 1990, it touched the landmark of 18.2 percent (Page, 1994). Four Asian emerging economies Hong Kong, Taiwan, South Korea, and Singapore achieved the miraculous growth from the 1960s to 1990s in excess of 6 percent pursuing rapid export-oriented industrialization stirs many of the developing countries to follow their model for development (Page, 1994; Lee et al, 2008; Mascelluti, 2015; World Bank, 2016).

The success of HPAEs inspired other South Asian economies to adopt export-led industrialization strategy as globalization policy (Chandra \& Sahoo, 2007), and Bangladesh is one of them. It has achieved remarkable economic growth immediately after the inception of trade liberalization in the late 1970s. The export performances of Bangladesh have shown in table 1. Since 1986 Bangladesh has adopted structural adjustment policies through trade liberalization measures to attain the objectives of greater openness and outward orientation. But it carries out significant trade policy reforms with the desire to shift the trade regime towards a liberalized one. The reform policies helped the economy to purge the adverse impact of past protection policies on exports which resulted in improved export performance and overall efficiency in resource allocation. Consequently, following slow growth in the 1980s, export has registered an increase to a double-digit rate over the last two decades and has exhibited spectacular growth performance in recent years registering a record growth at the rate of 14.75 percent. The contribution of export to GDP has maintained an increasing trend throughout the trade liberalization period and reached the record high over 19 percent in recent years. Subsequently, during the period of trade liberalization, it has been able to achieve higher economic growth, and the average GDP growth rate increased from 3.70 percent in the 1980 s to 5.8 percent in 2000s, and in recent years the economy has registered an average growth rate of 6.32 percent per annum (Ahmed, 2000).

Table 1: Export Performance of Bangladesh

\begin{tabular}{cccc}
\hline Year & GDP Growth & Export Growth & Export as \% of GDP \\
\hline $1981-1990$ & 3.70 & 8.22 & 5.16 \\
$1991-2000$ & 4.92 & 14.53 & 9.92 \\
$2001-2010$ & 5.80 & 11.19 & 14.67 \\
$2011-2015$ & 6.32 & 14.75 & 19.19 \\
\hline
\end{tabular}

Source: Bangladesh Economic Review, Various Issues 
Under such a setting, it is commonly perceived that the substantial growth performance that Bangladesh has experienced is attributed to the industrial sector growth resulting from gradual and continuous economic reforms to support export-substituting industrialization since the 1990s. Thus the study is primarily interested in investigating the validity of the ELG hypothesis for Bangladesh. It will first examine the long-run association between export and growth and then proceed to examine the short-run causality among the variables so as to achieve the main objective. A unidirectional causal relationship from export to output growth is necessary for the validity of the ELG hypothesis. However, bidirectional causality between export and output implies that growth in exports reinvigorates output growth which, in turn, reinforces export expansion and thereby further underlines the validity of ELG hypothesis (Mamun, et al., 2019).

The study is organized as follows: Following the introduction, section two reviews the literature on the ELG hypothesis with particular reference to Bangladesh. Methodology and data sources of the study are described in section three. Section four summarizes the empirical findings. Finally, the study ends with conclusions.

\section{LITERATURE REVIEW}

Studies on Latin American countries that have gone through rapid structural reforms during the last four decades provide a mixed result on the test of the ELG hypothesis. ELG is supported by studies like Riezman et al. (1996), Olson (2014), Siliverstovs and Herzer (2006), Agosin (1999) and Van den Berg and Schmidt (1994) while opposed by Awokuse (2008), Emirmahmutoglu and Kose (2011) and Dreger and Herzer (2013).

The abundance of empirical studies has been accompanied to examine the export-growth relationship of South and East Asian economies after their shift to export-led industrialization and find controversial results. Bahmani-Oskooee and Alse (1993), based on data of 9 developing countries, examine the export-growth nexus resorting cointegration and error correction mechanism and found profound support for the ELG hypothesis for all the states. Doganlar's (2004) findings indicate bi-directional causality for India, Philippines, Singapore, S. Korea, and Turkey though causality was unidirectional that goes from output to export growth for Sri Lanka and Pakistan and from export to output growth for Thailand. Similar results have been found by Shan and Sun (1998) for China and Khalafalla \& Webb (2001) and Baharumshah \& Rashid (1999) for Malaysia. Lee \& Huang (2002) find that the relationship whereby exports lead output prevails in at least one regime for each of four of the countries of South Asia, namely- Japan, Korea, Philippines, and Taiwan except Hong Kong. In contrast to the above findings studies like Chang et al. (2000), Mishra (2011) and Ghatak and Price (1997) reject the ELG hypothesis.

In the context of Bangladesh research findings presented in table 2 are also contrasting. While some studies find that growth in export has significantly stimulated growth of the economy (Paul, 2014; Sultan, 2008; Chandra \& Sahoo, 2007; Begum \& Shamsuddin, 1998; Hossain \& Karunaratne, 2004; Shirazi \& Manap, 2005; Al Mamun \& Nath, 2005; Paul, 2011; Islam \& Iftekharuzzaman, 1996), Ahmed and Uddin (2009) do not find any support in favour of ELG hypothesis for Bangladesh. The absence of uniform support regarding the ELG hypothesis both in theory and evidence, testing the hypothesis for the case of Bangladesh, mainly when recent year's data are not employed in earlier studies, would be valued worthy. 
Table 2: A Brief Literature Review on ELG for Bangladesh

\begin{tabular}{|c|c|c|c|c|}
\hline Study & Sample Period & Methodology & Variables & Conclusion \\
\hline $\begin{array}{l}\text { Begum \& } \\
\text { Shamsuddin } \\
\quad(1998)\end{array}$ & 1961-1992 & $\mathrm{ARCH}$ & $\begin{array}{l}\text { Per capita GDP, export- } \\
\text { GDP ratio, investment- } \\
\text { GDP ratio, annual } \\
\text { population growth rate }\end{array}$ & \multirow{6}{*}{$\begin{array}{l}\text { Support ELG } \\
\text { hypothesis }\end{array}$} \\
\hline $\begin{array}{c}\text { Hossain \& } \\
\text { Karunaratne } \\
(2004) \\
\end{array}$ & 1974-1999 & $\begin{array}{c}\text { Johansen } \\
\text { Cointegration }\end{array}$ & $\begin{array}{l}\text { Exports (total and } \\
\text { manufacturing), imports } \\
\text { and non-export GDP }\end{array}$ & \\
\hline $\begin{array}{l}\text { Al Mamun \& } \\
\text { Nath }(2005)\end{array}$ & $\begin{array}{c}\text { 1976:1-2003:4, } \\
\text { quarterly data }\end{array}$ & Granger-causality & $\begin{array}{l}\text { Exports and industrial } \\
\text { production index }\end{array}$ & \\
\hline $\begin{array}{c}\text { Chandra \& } \\
\text { Sahoo (2007) }\end{array}$ & $1980-2002$ & $\begin{array}{c}\text { Panel } \\
\text { Cointegration } \\
\end{array}$ & $\begin{array}{l}\text { Exports, imports, gross } \\
\text { capital formation, GDP }\end{array}$ & \\
\hline Sultan (2008) & $1965-2004$ & $\begin{array}{c}\text { Johansen } \\
\text { Cointegration }\end{array}$ & $\begin{array}{l}\text { Exports, imports, industry } \\
\text { value added and GDP }\end{array}$ & \\
\hline Paul (2011) & $1979-2010$ & ARDL & Exports, imports and GDP & \\
\hline $\begin{array}{c}\text { Shirazi \& } \\
\text { Manap (2005) }\end{array}$ & $1973-2002$ & Granger-causality & Exports, imports, and GDP & \multirow{2}{*}{$\begin{array}{c}\text { Bidirectional } \\
\text { Causality } \\
\text { between exports } \\
\text { and GDP growth }\end{array}$} \\
\hline Paul (2014) & $1979-2010$ & $\begin{array}{c}\text { Johansen } \\
\text { Cointegration } \\
\end{array}$ & Exports, imports and GDP & \\
\hline $\begin{array}{l}\text { Ahmed and } \\
\text { Uddin (2009) }\end{array}$ & $1976-2005$ & $\begin{array}{l}\text { Granger } \\
\text { Causality }\end{array}$ & $\begin{array}{l}\text { Exports, imports, } \\
\text { remittance and GDP }\end{array}$ & $\begin{array}{c}\text { Does not support } \\
\text { the ELG } \\
\text { hypothesis }\end{array}$ \\
\hline
\end{tabular}

Source: Constructed by authors based on literature survey

\section{DATA SOURCES, MODEL SPECIFICATION, AND METHODOLOGY}

\section{II.I. Sources of Data}

Earlier empirical studies have commonly used the real GDP in examining the export-growth relationship, and one of the most obvious problems of these studies is that the findings may be spurious as GDP includes export as one of its components. To avoid such problem, empirical analysis of this study employs annual secondary data of the industrial production index which is seasonally adjusted for the year 2010 collected from IFS, IMF.

Table 3: ADF and PP Test for Stationarity

\begin{tabular}{|c|c|c|c|c|c|c|}
\hline \multirow{2}{*}{ Variables } & \multirow{2}{*}{ Test in } & \multirow{2}{*}{ Includes } & \multicolumn{2}{|c|}{$\underline{\mathrm{ADF}}$} & \multicolumn{2}{|c|}{$\underline{\mathrm{PP}}$} \\
\hline & & & t-statistic & $\mathrm{p}$-value & $\mathrm{t}$-statistic & p-value \\
\hline \multirow{2}{*}{$\begin{array}{l}\text { Industrial } \\
\text { Production } \\
\text { Index, INP }\end{array}$} & Level & Trend, Intercept & $-2.179(0)$ & 0.488 & $-2.630(3)$ & 0.270 \\
\hline & First Difference & Trend, Intercept & $-8.363(0)$ & $0.000 *$ & $-8.315(2)$ & $0.000 *$ \\
\hline \multirow{2}{*}{ Exports, EXP } & \multirow{2}{*}{ Level } & Intercept & $0.587(0)$ & 0.988 & $0.442(2)$ & 0.982 \\
\hline & & Trend, Intercept & $-1.440(0)$ & 0.834 & $-1.543(2)$ & 0.798 \\
\hline \multirow{4}{*}{$\begin{array}{l}\text { Imports, } \\
\text { IMP }\end{array}$} & \multirow{2}{*}{ Level } & Intercept & $0.200(0)$ & 0.969 & $0.549(9)$ & 0.986 \\
\hline & & Trend, Intercept & $-2.099(0)$ & 0.531 & $-1.937(6)$ & 0.617 \\
\hline & \multirow{2}{*}{ First Difference } & Intercept & $-7.913(0)$ & $0.000^{*}$ & $-7.915(3)$ & $0.000^{*}$ \\
\hline & & Trend, Intercept & $-8.158(0)$ & $0.000 *$ & $-8.983(8)$ & $0.000^{*}$ \\
\hline $\begin{array}{c}\text { Gross Fixed } \\
\text { Capital, } \\
\text { CAP }\end{array}$ & Level & Intercept & $-0.606(0)$ & 0.858 & $-0.604(3)$ & 0.859 \\
\hline
\end{tabular}

Note: ${ }^{*}$ Significant at $1 \%$ level

** Significant at $5 \%$ level

Numbers within brackets for the ADF and PP tests indicates the lag numbers in the test regression to confirm white noise error and the choice of truncational lag length in the test, respectively. 
The data on exports, imports, and investment proxied by the formation of gross fixed capital are collected from WDI (World Development Indicators) of the World Bank (2016). Value of the data used as the US dollar and year 2010 considered as the base year. It covers the period from 1974 to 2015. The logarithmic values of the variables are used to avoid the problem of heteroscedasticity. The study than performs Augmented-Dickey-Fuller (ADF) t-tests and Phillips-Perron (PP) Z (t $\alpha$ ) tests to determine the degree of integration of the series. Test results are summarised in table 3. All the variables are found stationary at first difference level, and hence all the variables are I(1) processes as their order of integration is 1 .

\section{II.II. Model Specification and Methodology}

As the series of the variables are found to be integrated of order 1, the Engle-Granger method can be applied to examine whether the variables are cointegrated or not. But the technique is criticised as to include small sample bias due to the exclusion of short-run dynamics. One can also employ the Johansen cointegration method to test the long-run association between the variables that require a large sample size for the validity of the results (Ghatak \& Siddiki, 2001). As the study relies on a small sample size, it applies the procedure of ARDL Bounds testing approach that can overcome the limitation of small sample bias more efficiently than any other techniques. This technique is reported to have several benefits. It reduces the number of parameters to be estimated as it relies on a single ARDL equation instead of depending on a VAR as in Johansen. The approach is also different from the Johansen's proposal as it imposes restrictions on the number of lags to each of the variables individually. The ARDL approach in identifying the existence of a long-run relationship is appropriate regardless of whether the underlying regressors are $\mathrm{I}(0), \mathrm{I}(1)$ or mutually cointegrated (Pesaran et al., 2001).

Following the conventional Error Correction Model (ECM) for cointegrating variables, the ARDL scheme for the study is given.

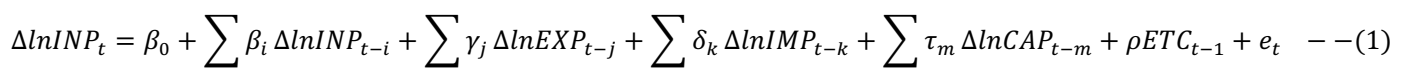

Here, ECT, the "error-correction term", is the OLS residual series derived from the long-run cointegrating regression model given as-

$$
\operatorname{lnINP_{t}}=a_{1}+a_{2} \ln E X P_{t}+a_{3} \ln I M P_{t}+a_{4} \ln C A P_{t}+u_{t}----------------(2)
$$

As ELG hypothesis assumes export fosters GDP growth, $\mathrm{a}_{2}$ is expected to be positive and so is $\mathrm{a}_{4}$ since capital formation leads to expansion of domestic output increasing the productive capacity of an economy, while the import is expected to have a negative influence of import on the economy. Hence, $\mathrm{a}_{2}, \mathrm{a}_{4}>0$ and $\mathrm{a}_{3}<0$.

The approach 'ARDL Bounds testing' is applicable for series that are I(0), I(1), or mutually cointegrated, but none of them is I(2). As ADF and PP tests as summarized in table 03 confirm all the variables are integrated of order 1 , one can proceed for the estimation of the following ARDL scheme-

$$
\begin{aligned}
\Delta \ln I N P_{t}=\beta_{0}+\sum_{+\beta_{3}} \beta_{i} \Delta \ln I N P_{t-i}+\sum \gamma_{j} \Delta \ln E X P_{t-j}+\sum \rho_{4} \ln C A P_{t-1}+e_{t} \Delta \operatorname{lnIMP} P_{t-k}+\sum \tau_{m} \Delta \ln C A P_{t-m}+\rho_{1} \ln I N P_{t-1}+\rho_{2} \ln E X P_{t-1} \\
\end{aligned}
$$

An ARDL scheme in (3) free from serial correlation as well as stable allows proceeding for Bounds testing to examine the presence of long-run cointegrating relationship taking null hypothesis $\mathrm{H}_{0}: \rho_{1}=\rho_{2}=\rho_{3}=\rho_{4}=0$ into account. The existence of long-run association requires rejecting $\mathrm{H}_{0}$. The presence of a long-run relationship will determine whether the long-run estimates of coefficients and ECM would be necessary or not to describe the equilibrium relationship between growth and export in the long-run. Furthermore, a unidirectional long-run association from export to economic growth 
is crucial for the validity of the ELG hypothesis. To investigate whether there prevails a unidirectional relationship from export to economic growth, the study repeats the same exercise mentioned above by treating export as a dependent variable.

As an alternative to the conventional Granger Causality test, the study also performs the TodaYamamoto causality test. Conventional causality test is based on F-statistic that does not have a standard distribution due to which the causality test results become fragile and may not be able to generate robust results. Toda-Yamamoto (1995) offers a simple procedure to overcome this problem that estimates an Augmented VAR ( $\mathrm{k}+\mathrm{dmax})$ where $\mathrm{k}$ is the lag length in the system and dmax is the maximal order of integration suspected to occur in the system. The VAR thus estimated generates a modified WALD (MWALD) test statistic that follows an asymptotic Chi-square distribution. This procedure is particularly useful for its congeniality whether the VAR is stationary (around a deterministic trend), integrated of arbitrary order, or cointegrated of arbitrary order. Accordingly, one can test the linear or nonlinear restrictions on the coefficients by estimating a level VAR and employing the WALD criterion, paying little attention to the integration and cointegration properties of the time series data in hand (Toda and Yamamoto, 1995). The VAR system in order to perform the Toda and Yamamoto (1995) version of the Granger non-causality test between export and ouput can be given as:

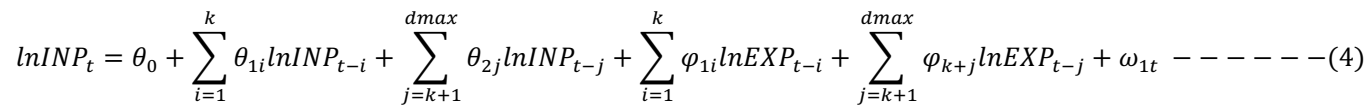

$$
\begin{aligned}
& \ln E X P_{t}=\rho_{0}+\sum_{i=1}^{k} \rho_{1 i} \ln E X P_{t-i}+\sum_{j=k+1}^{d \max } \rho_{2 j} \ln E X P_{t-j}+\sum_{i=1}^{k} \tau_{1 i} \operatorname{lnINP_{t-i}}+\sum_{j=k+1}^{d \max } \tau_{k+j} \operatorname{lnIN} P_{t-j}+\omega_{2 t}-----(5)
\end{aligned}
$$

The null hypotheses "no Granger causality from lnEXP to lnINP" for equation 4 and "no Granger causality from $\operatorname{lnINP}$ to $\operatorname{lnEXP"}$ " for equation 5 are defined by $\mathrm{H}_{0}: \varphi_{1 i}=0$ and by $\mathrm{H}_{0}$ : $\tau_{1 i}=0$, respectively.

\section{EMPIRICAL RESULTS}

The appropriate number of lags for each variable to include in the estimation is selected by AIC (Akaike Information Criteria) that offers an ARDL $(1,0,4,1)$ scheme to assess the long-run cointegrating relationship. The procedure of selecting the optimal lag length and appropriate ARDL scheme is summarized in the appendix (table-A and figure-1). With regard to the compatibility test results summarized in table B in the appendix, the estimated ARDL $(1,0,4,1)$ model passes the serial correlation LM test and test of heteroskedasticity meaning that errors are serially independent and free from the problem heteroskedastic variance. The model is also found stable as it passes the recursive estimates CUSUM test as shown in figure 2 in the appendix. Therefore, the model is applicable for Bounds testing to identify whether cointegrating relationship prevails among the variables in the long run that considers the $\mathrm{H}_{0}: \rho_{1}=\rho_{2}=\rho_{3}=\rho_{4}=0$, rejection of which leads to the conclusion that there prevails a long-run association between export and growth.

Table 4: Bounds test for examining the existence of co-integrating relation

\begin{tabular}{lcccc}
\hline Regressands & F-statistics & \multicolumn{2}{c}{ Critical Value Bounds* $^{*}$} \\
& & Significance & Lower Bound & Upper Bound \\
\hline INP & 10.025 & $10 \%$ & 2.37 & 3.2 \\
EXP & 7.146 & $5 \%$ & 2.79 & 3.67 \\
IMP & 11.325 & $2.5 \%$ & 3.15 & 4.08 \\
CAP & 13.551 & $1 \%$ & 3.65 & 4.66 \\
\hline Note: * Pesaran Critical Values & & &
\end{tabular}


The results of Bounds test summarised in the table- 4 show that the null hypotheses for all dependent variables are rejected as the value of $\mathrm{F}$-statistics exceed the reported critical values for $5 \%$ levels of significance, which suggest that the long-run cointegrating associations that exist among the variables are not unique. Thus, the export-growth relationship is not unidirectional, which is the pre-condition for the validity of the ELG hypothesis.

The presence of long-run association permits the researcher to evaluate dynamics in the shortrun and the correction towards equilibrium in the long-run. Table-5 shows the results of the long-run model shown by equation (2). The results are significant, and coefficients maintain the expected signs. It is evident that the increase in exports contributes positively to economic growth in the long run. Hence, ELG is evident for Bangladesh in the long-run. Likewise, gross capital formation has a positive influence on output, while the impact of imports is negative.

Table 5: Long-Run ELG Equation

\begin{tabular}{ccccc}
\hline Regressor & Coefficient & Std. Error & t-Statistic & Prob. \\
\hline $\ln E X P_{t}$ & $0.533^{*}$ & 0.184 & 2.896 & 0.008 \\
$\ln I M P_{t}$ & $-0.312^{* *}$ & 0.176 & -1.774 & 0.088 \\
$\ln C A P_{t}$ & $0.498^{*}$ & 0.112 & 4.460 & 0.000 \\
Constant & $-12.443^{*}$ & 1.638 & -7.597 & 0.000 \\
\hline
\end{tabular}

Sources: Authors' calculation

Note: $\quad$ The notations $*$ and $* *$ show the statistics are significant at $1 \%$ and $\%$ level, respectively

The dynamic ECM of economic growth based on ARDL $(1,0,4,1)$ is reported in table- 6 . Statistically significant short-run coefficients had found in the table. The coefficient associated with the error-correction term $\mathrm{ECT}_{\mathrm{t}-1}$ measure the speed at which the system adjusts towards equilibrium in the long-run, and it has to be negative and significant to ensure convergence to the equilibrium in the long-run. Here, the coefficient of ECT is negative and highly significant, meaning that the system gets back to long-run equilibrium at the rate of 31.5 percent at the end of each period. The model passes the test of serial correlation and also stable.

Table 6: Error Correction Estimates for ARDL Model

\begin{tabular}{ccccc}
\hline Regressor & Coefficient & Std. Error & t-Statistic & Prob. \\
\hline$\Delta \ln E X P_{t}$ & $0.213^{*}$ & 0.055 & 3.916 & 0.001 \\
$\Delta \ln I M P_{t}$ & $-0.150^{*}$ & 0.039 & -3.761 & 0.001 \\
$\Delta \operatorname{lnIM} P_{t-1}$ & 0.005 & 0.024 & 0.215 & 0.832 \\
$\Delta \ln I M P_{t-2}$ & -0.026 & 0.023 & -1.156 & 0.258 \\
$\Delta \ln I M P_{t-3}$ & $-0.056^{* *}$ & 0.021 & -2.673 & 0.013 \\
$\Delta \ln C A P_{t}$ & $0.667^{*}$ & 0.069 & 9.562 & 0.000 \\
$E C T_{t-1}$ & $-0.315^{*}$ & 0.048 & -6.515 & 0.000 \\
\hline Sources: Authors calculation & & \\
Note: The notations * and ** show the statistics are significant at $1 \%$ and
\end{tabular}

With regard to short-run causality among the variables, Granger's Wald test results that are shown in table 7. Test results indicate that the null hypothesis of the absence of causal relationship both from exports to economic growth and from economic growth to exports are rejected at 5 percent significant level, meaning that the export-growth relationship is bidirectional in the short-run as well. A unidirectional causal relationship from export to output growth is the precondition for the validity of the ELG hypothesis. However, bidirectional causality between export and output running from output growth to exports, in turn, reinforce output growth and thereby further underline the validity of the ELG hypothesis. 
Table 7: Results from the Wald Test

\begin{tabular}{ccc}
\hline Null Hypothesis & F-Statistic & p-value \\
\hline EXP $\neq>$ INP & $7.750^{*}$ & 0.005 \\
INP $\neq>$ EXP & $26.053^{*}$ & 0.000 \\
IMP $\neq>$ INP & $11.168^{* *}$ & 0.048 \\
CAP $\neq>$ INP & $12.983^{*}$ & 0.002 \\
\hline
\end{tabular}

Sources: Authors' calculation

Note: $\neq>$ implies 'does not cause', The notations * and ** show the statistics are significant at $1 \%$ and $5 \%$ level, respectively

In order to perform the Toda-Yamamoto Granger non-causality test, the lag order of the VAR model is set to 4 and the dmax is set to 1 as the maximum order of integration. The test results are summarized in table 8 . Test results suggest that the causality between export and output growth is unidirectional that runs from export to output growth and thus necessarily support the ELG hypothesis for Bangladesh. Unlike conventional causality test, it does not find any evidence that output growth, in turn, supports export expansion. However, both of the tests find that imports and formation of gross fixed capital cause short-run economic growth.

Table 8: Toda Yamamoto Granger Non-Causality Test

\begin{tabular}{ccc}
\hline Null Hypothesis & MWALD $\sim$ Chi-square & P-values for WALD \\
\hline EXP $\neq>$ INP & $7.844585^{* *}$ & 0.0974 \\
INP $\neq>$ EXP & 4.833634 & 0.3048 \\
IMP $\neq>$ INP & $6.390826^{* *}$ & 0.0941 \\
CAP $\neq>$ INP & $10.55126^{*}$ & 0.0144 \\
\hline
\end{tabular}

Sources: Authors' calculation

Note: The notation $\neq>$ implies non-causality. The notations * and ** show the statistics are significant at 5\% and $10 \%$ level, respectively and thus reject the null hypothesis of the absence of a casual relationship.

\section{CONCLUSION}

The substantial export growth and its rising share in GDP over the last three decades with an accelerated economic growth have triggered the expectation of ELG hypothesis will be turned into a real phenomenon for the case of Bangladesh. The long-run dynamics between export and output growth based on ARDL Bounds testing approach suggests that exports support the growth of Bangladesh economy positively in the long run, and the system has a tendency of getting back to the long-run equilibrium correcting its short-run deviations at the rate of 31.5 percent per period. In order to examine the short-run causality, the study performs Toda-Yamamoto causality test along with the conventional Granger causality test. While the Granger causality analysis identifies a bidirectional causal relationship between exports and output growth, the Toda-Yamamoto approach confirms a unidirectional causality that runs from exports to output growth. A unidirectional causal relationship from export to output growth is necessary for the validity of the ELG hypothesis. However, bidirectional causality between export and output implies that expansion in exports reinvigorates economic growth which, in turn, reinforces export expansion and the process continues which further underlines the validity of the ELG hypothesis. The short-run positive impact of the formation of gross fixed capital is found to be sustained in the long run. The import variable as well satisfies the theoretical expectation in exerting its impact on the growth of the economy. A statistically significant export variable coefficient in the long run in association with gross fixed capital formation can be interpreted as an improvement in efficiency meaning that the economy manages to upgrade technology and improve factor productivity, both of which are inevitable for the long-term growth of Bangladesh. 


\section{REFERENCES}

Agosin, M. R. (1999). Trade and growth in Chile. Cepal Review, 68, 1658-95

Ahmed, H. A., \& Uddin, M. G. S. (2009). Export, imports, remittance and growth in Bangladesh: An empirical analysis. Trade and Development Review, 2(2).

Ahmed, N. (2000). Export response to trade liberalization in Bangladesh: a cointegration analysis. Applied Economics, 32(8), 1077-1084.

Al Mamun, K. A., \& Nath*, H. K. (2005). Export-led growth in Bangladesh: a time series analysis. Applied Economics Letters, 12(6), 361-364.

Awokuse, T. (2008). “Trade Openness and Economic Growth: Is Growth Export-Led or Import- Led?” Applied Economics 40, no. 2: 161-173.

Awokuse, T. O. (2003). Is the export-led growth hypothesis valid for Canada?, Canadian Journal of Economics, 36(1), pp. 126-136.

Baharumshah, A. Z., \& Rashid, S. (1999). Exports, Imports and Economic Growth in Malaysia: EmpiricalEvidence Based on Multivariate Time Series. Asian Economic Journal, 13(4), 389-406.

Bahmani-Oskooee, M. and Janardhanan Alse (1993). Export growth and economic growth: An application of cointegration and error-correction modeling. The Journal of Developing Areas, 27(4), 535-542.

Balassa, B. (1978) 'Exports and economic growth: further evidence'. Journal of Development Economics 5(2), $181-189$.

Begum, S., \& Shamsuddin, A. F. (1998). Exports and economic growth in Bangladesh. The Journal of Development Studies, 35(1), 89-114.

Chandra Parida, P., \& Sahoo, P. (2007). Export-led growth in South Asia: a panel cointegration analysis. International Economic Journal, 21(2), 155-175.

Chang, T., Fang, W., Liu, W., \& Henry, T. (2000). Exports, imports and income in Taiwan: An examination of the export led growth hypothesis. International Economic Journal, 14(2), 151-160.

Doganlar, M. (2004). Export-led growth hypothesis in Asian countries: cointegration and causality analysis. Indian Journal of Economics, 84(2), 683-694.

Dornbusch, R., Fischer, S., \& Samuelson, P. A. (1980). Heckscher-Ohlin trade theory with a continuum of goods. The Quarterly Journal of Economics, 203-224.

Dreger, C., and D. Herzer. 2013. "A Further Examination of the Export-Led Growth Hypothesis." Empirical Economics 45, no. 1: 39-60.

Emirmahmutoglu, F., and N. Kose. (2011). "Testing for Granger Causality in Heterogeneous Mixed Panels." Economic Modeling 28, no. 3: 870-876.

Ghatak, S., \& Price, S. W. (1997). Export Composition and Economic Growth: Cointegration and Causality Evidence for India. Review of World Economics, 133, 538-553.

Ghatak, S., \& Siddiki, J. U. (2001). The use of the ARDL approach in estimating virtual exchange rates in India. Journal of Applied statistics, 28(5), 573-583.

Heckscher, E. F., \& Ohlin, B. G. (1991). Heckscher-Ohlin trade theory. The MIT Press.

Helpman, E. and Krugman, P. (1985) Market Structure and Foreign Trade. Cambridge, MA: MIT Press.

Hossain, M., \& Dias Karunaratne, N. (2004). Exports and economic growth in Bangladesh: Has manufacturing exports become a new engine of export-led growth?. The international trade journal, 18(4), 303334.

Doganlar, M. (2004). Export-led growth hypothesis in Asian countries: cointegration and causality analysis. Indian Journal of Economics, 84(2), 683-694.

Dornbusch, R., Fischer, S., \& Samuelson, P. A. (1980). Heckscher-Ohlin trade theory with a continuum of goods. The Quarterly Journal of Economics, 203-224.

Dreger, C., and D. Herzer. 2013. "A Further Examination of the Export-Led Growth Hypothesis." Empirical Economics 45, no. 1: 39-60.

Emirmahmutoglu, F., and N. Kose. (2011). "Testing for Granger Causality in Heterogeneous Mixed Panels." Economic Modeling 28, no. 3: 870-876.

Ghatak, S., \& Price, S. W. (1997). Export Composition and Economic Growth: Cointegration and Causality Evidence for India. Review of World Economics, 133, 538-553. 
Ghatak, S., \& Siddiki, J. U. (2001). The use of the ARDL approach in estimating virtual exchange rates in India. Journal of Applied statistics, 28(5), 573-583.

Heckscher, E. F., \& Ohlin, B. G. (1991). Heckscher-Ohlin trade theory. The MIT Press.

Helpman, E. and Krugman, P. (1985) Market Structure and Foreign Trade. Cambridge, MA: MIT Press.

Hossain, M., \& Dias Karunaratne, N. (2004). Exports and economic growth in Bangladesh: Has manufacturing exports become a new engine of export-led growth?. The international trade journal, 18(4), 303334.

Mamun, A., Bal, H., \& Akca, E. E. (2019). The export-output growth nexus in Bangladesh: a leveraged bootstrap approach. Journal of Asia Business Studies, 13(2), 196-213.

Mascelluti, E. (2015). The extraordinary growth of the four Asian tigers, Department of Economics and Finance, LUISS Guido Carli, Italy.

Mishra, P. K. (2011). The Dynamics of Relationship between exports and economic growth in India. International Journal of Economic Sciences and Applied Research 4(2), 53-70.

Olson, J. E. (2014). Economic Growth in Latin American Countries: Is It Based on Export-Led or Import-Led Growth? Emerging Markets Finance and Trade, 50(sup1), 6-20.

Page, J. (1994). The East Asian miracle: four lessons for development policy. In NBER Macroeconomics Annual 1994, Volume 9 (pp. 219-282). MIT Press.

Paul, B. P. (2011). Revisiting export-led growth for Bangladesh: A synthesis of cointegration and innovation accounting. International Journal of Economics and Finance, 3(6), 3.

Paul, B. P. (2014). Testing export-led growth in Bangladesh: An ARDL bounds test approach. International Journal of Trade, Economics and Finance, 5(1), 1.

Pesaran, M. H., Shin, Y., \& Smith, R. J. (2001). Bounds testing approaches to the analysis of level relationships. Journal of applied econometrics, 16(3), 289-326.

Riezman, R.G.; P.M. Summers; and C.H. Whiteman. (1996). "The Engine of Growth or Its Handmaiden? A Time-Series Assessment of Export-Led Growth.” Empirical Economics 21, no. 1: 77-113.

Shan, J., \& Sun, F. (1998). On the export-led growth hypothesis: the econometric evidence from China. Applied Economics, 30(8), 1055-1065.

Shirazi, N. S., \& Manap, T. A. A. (2005). Export-led growth hypothesis: further econometric evidence from South Asia. Developing Economies, 43(4), 472-488.

Siliverstovs, B., \& Herzer, D. (2006). Export-led growth hypothesis: evidence for Chile. Applied Economics Letters, 13(5), 319-324.

Sultan, P. (2008). Trade, industry and economic growth in Bangladesh. Journal of Economic cooperation, 29(4), 71-92.

Toda, H. Y. \& Yamamoto, T. (1995), "Statistical inference in vector autoregressions with possibly integrated processes", Journal of Econometrics, Vol. 66, pp. 225-250.

Van den Berg, H., and J.R. Schmidt. (1994). "Foreign Trade and Economic Growth: Time Series Evidence from Latin America." Journal of International Trade and Economic Development 3, no. 3: 249268.

World Bank, World Development Indicators, 2016. 


\section{Appendix}

\section{Tables}

Table-A: Optimal Lag Selection

\begin{tabular}{ccccccc}
\hline Lag & LogL & LR & FPE & AIC & SC & HQ \\
\hline \hline 0 & 32.74126 & NA & $2.27 \mathrm{e}-06$ & -1.642358 & -1.464604 & -1.580997 \\
1 & 212.3533 & 307.9064 & $1.99 \mathrm{e}-10$ & -10.99162 & $-10.10285^{*}$ & $-10.68482^{*}$ \\
2 & 226.1148 & 20.44566 & $2.36 \mathrm{e}-10$ & -10.86371 & -9.263919 & -10.31146 \\
3 & 239.8960 & 17.32482 & $2.96 \mathrm{e}-10$ & -10.73691 & -8.426109 & -9.939223 \\
4 & 267.2135 & $28.09805^{*}$ & $1.91 \mathrm{e}-10^{*}$ & $\mathbf{- 1 1 . 3 8 3 6 3 *}$ & -8.361809 & -10.34050 \\
\hline \hline
\end{tabular}

* indicates lag order selected by the criterion

LR: sequential modified LR test statistic (each test at 5\% level)

FPE: Final prediction error

AIC: Akaike information criterion

SC: Schwarz information criterion

HQ: Hannan-Quinn information criterion

The appropriate number of lags to be included in the estimation is selected by AIC (Akaike Information Criteria).

Table-B: Compatibility Tests- Tests for Serial Correlation and Heteroskedasticity

\begin{tabular}{ccc}
\hline Test & F-statistic & p-value \\
\hline Serial Correlation LM Test & 0.8099 & 0.5322 \\
Heteroskedasticity & 0.3123 & 0.9637 \\
\hline
\end{tabular}

The null hypothesis of 'no serial correlation' is accepted at a 5 percent level of significance and therefore the model is free from autocorrelation problem. Again, the null hypothesis of 'homoskedasticity' is accepted at a 5 percent level of significance and therefore the model is free from the problem heteroskedastic variance. 


\section{Figures}

Figure-1: Selection of Appropriate ARDL Scheme Akaike Information Criteria (top 20 models)

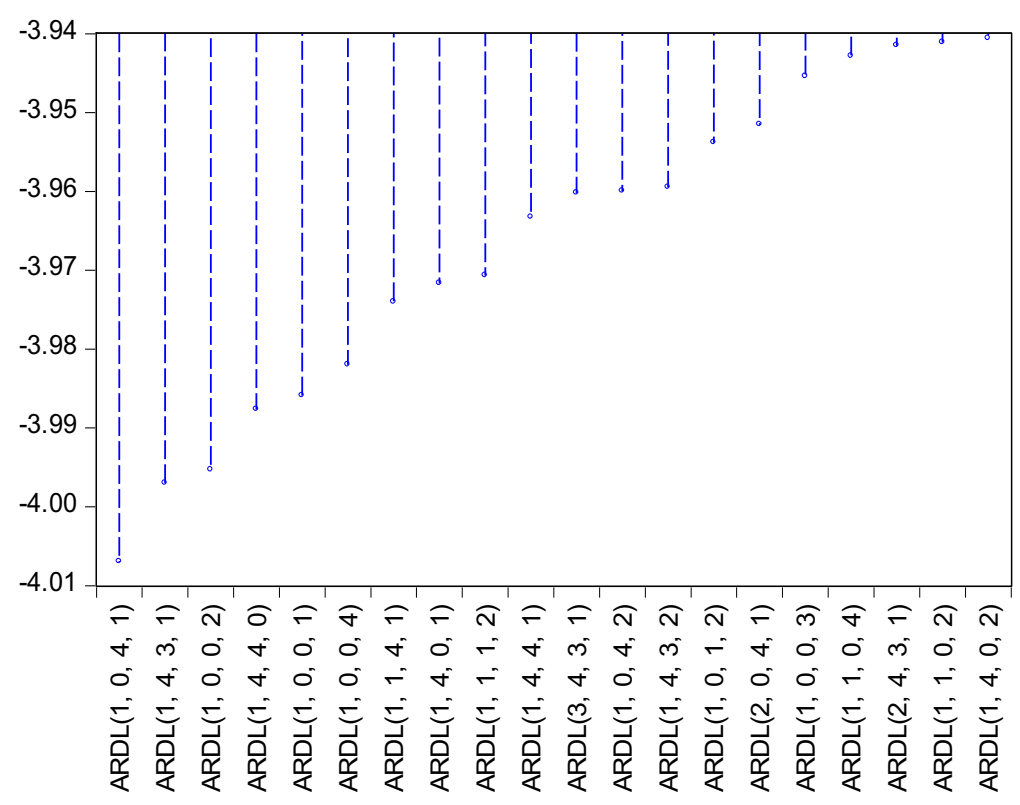

Figure-2: Stability Diagnosis- CUSUM Test

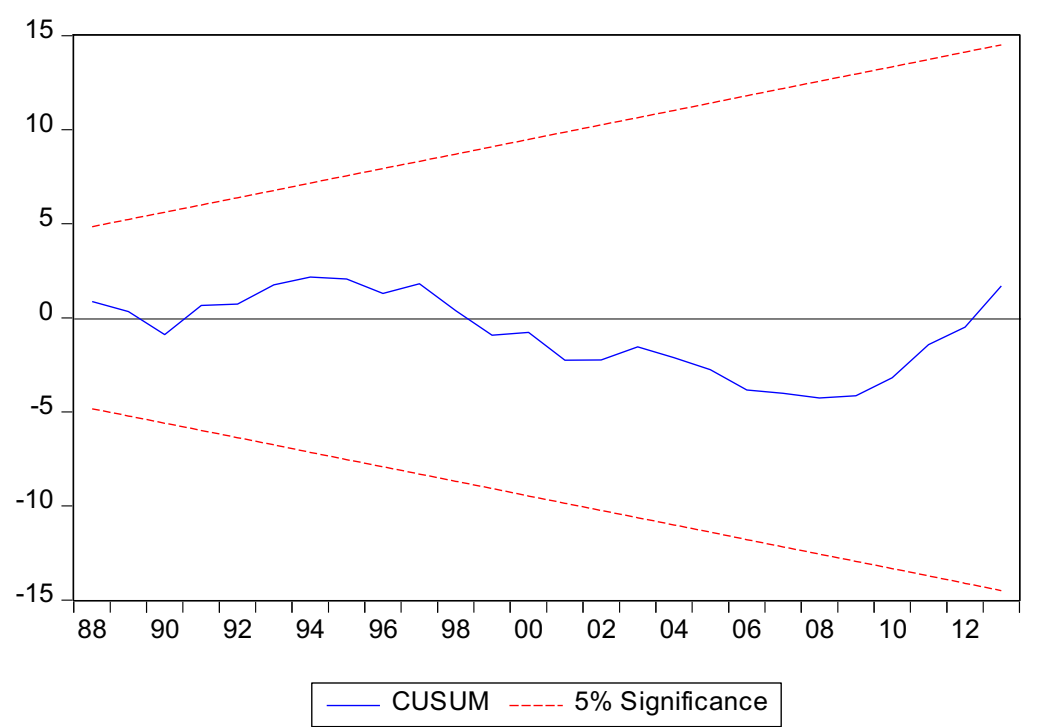

As the CUSUM series lies within the upper and lower critical values, therefore the model is structurally stable. 